\title{
Preferensi Pengguna Angkutan Umum Penumpang di Kota Makassar
}

\section{Preference of Public Transport Passengers in Makassar City}

\author{
Aslam Jumain¹, Murshal Manaf², Qadriathi Dg. Bau ${ }^{3}$ \\ 1Mahasiswa Program Studi Perencanaan Wilayah dan Kota Program Pascasarjana Universitas Bosowa \\ ${ }^{2}$ Program Studi Perencanaan Wilayah dan Kota, Program Pascasarjana, Universitas Bosowa \\ ${ }^{3}$ Program Studi Pendidikan Teknik Sipil dan Perencanaan, Fakultas Teknik, Universitas Negeri Makassar \\ E-mail: aslamjumain@gmail.com
}

Diterima: 20 Februari 2021/Disetujui 07 Juni 2021

\begin{abstract}
Abstrak. Penelitian ini bertujuan untuk mengakaji, menganalisis dan menginterpertasi; karakteristik penggunaan angkutan umum di Kota Makassar berdasarkan preferensi masyarakat dalam menggunakan angkutan umum dan pengaruh tingkat pelayanan angkutan umum terhadap preferensi menggunakan angkutan umum di Kota Makassar.. Penelitian ini merupakan bersifat deskriptif analisis dengan menggunakan pendekatan kuantitatif. Data diperoleh dari hasil kuisioner menggunakan skala likert dan kuisioner karakteristik penggunaan angkutan umum. Variabel yang digunakan adalah karakteristik sosial ekonomi, karakteristik spasial, ciri pergerakan, ciri fasilitas moda, kualitas pelayanan dan kinerja angkutan umum. Analisa yang digunakan yaitu analisis statistik deskriptif. Hasil analisis menunjukkan perbedaan penggunaan antara angkutan kota dan angkutan berbasis online. Masyarakat cenderung menggunakan angkutan kota karena waktu terjadinya perjalanan dan biaya transportasi, sedangkan masyarakat cenderung menggunakan angkutan online karena waktu perjalanan dan aksesibilitas

Kata Kunci: Karakteristik Pengguna, Angkutan Perkotaan, Preferensi Pengguna, Makassar

Abstract. This study aims to assess, analyze and interpret; The characteristics of the use of public transportation in Makassar City based on people's preferences in using public transportation and the influence of the level of public transport services on preferences for using public transportation in Makassar City. This research is a descriptive analysis using a quantitative approach. Data obtained from questionnaires using a Likert scale and questionnaires on the characteristics of the use of public transportation. The variables used are socio-economic characteristics, spatial characteristics, movement characteristics, mode facilities characteristics, service quality and public transport performance. The analysis used is descriptive statistical analysis. The analysis results show the difference in use between city transportation and online-based transportation. People tend to use city transportation because of travel time and transportation costs, while people tend to use online transportation because of travel time and accessibility.
\end{abstract}

Keywords: User Characteristics, Urban Transport, User Preference, Makassar

\section{Pendahuluan}

Transportasi merupakan kebutuhan yang tidak dapat dipisahkan dari kehidupan manusia. Terdapat hubungan erat antara lokasi dan lokasi kegiatan manusia. Pentingnya transportasi terlihat dengan semakin meningkatnya kebutuhan akan jasa angkutan bagi mobilitas orang serta barang dari dan ke seluruh pelosok tanah air bahkan dari dan ke luar negeri (Tamin, 2000). Ditinjau dari konteks sistem transportasi kota, angkutan umum merupakan bagian yang tak terpisahkan dari sistem transportasi kota, dan merupakan komponen yang perannya sangat signifikan. Jaringan jalan merupakan simpul penyambung dan konektifitas antara sarana perhubungan lainnya, seperti Pelabuhan (Harsono et al, 2020). Dikatakan signifikan karena kondisi sistem angkutan umum yang jelek akan menyebabkan turunnya efektivitas maupun efisiensi dari sistem transportasi kota secara keseluruhan. Hal ini akan menyebabkan terganggunya sistem kota secara keseluruhan, baik ditinjau dari pemenuhan kebutuhan mobilitas masyarakat maupun ditinjau dari mutu kehidupan kota. Alasan utama yang dapat menjelaskan mengapa peran angkutan umum sangat penting dalam sistem kota adalah kenyataan bahwa angkutan umum adalah sarana yang dibutuhkan oleh sebagian besar masyarakat kota. Artinya, tidaklah mungkin sebuah kota dapat hidup tanpa angkutan umum. Dikatakan sebagian besar masyarakat kota membutuhkan angkutan umum, karena bagaimanapun pasti ada sekelompok masyarakat yang tergantung pada angkutan umum untuk memenuhi kebutuhan mobilitasnya dengan alasan tidak dapat menggunakan kendaraan pribadi, baik karena alasan fisik (terlalu kecil, sakit), alasan legal (SIM) atau alasan finansial.

Kondisi tersebut sangat berpengaruh terhadap perencanaan transportasi agar tujuan adanya transportasi dapat terpenuhi secara maksimal. Kota Makassar sebagai gerbang Kawasan Indonesia Timur (KTI) merupakan ibukota Provinsi Sulawesi Selatan jumlah penduduk 1.526.677 jiwa (Kota Makassar Dalam Angka, 2020). Kepadatan penduduk di Kota Makasssar tahun 2019 mencapau 8.686 jiwa/km2. Kepadatan penduduk di 15 kecamatan cukup beragam dengan kepdatan penduduk 
tertinggi terletak di Kecamatan Makassar dengan kepdatan sebesar 33.935 jiwa/km2 dan trendah di Kecamatan Tamalanrea sebesar $3.638 \mathrm{jiwa} / \mathrm{km} 2$ (Kota Makassar dalam Angka, 2020). Dari besarnya perbedaan kepdatan penduduk yang tinggi tersebut dapat dilihat bahwa persebaran penduduk di Kota Makassar tidak merata, sehingga ini membawa implikasi terkumpulnya pusat-pusat aktivitas warga di daerah-daerah tertentu. Secara tidak langsung diikuti oleh kebutuhan masyarakat akan transportasi akan meningkat.

Pada saat ini, di Kota Makassar memiliki moda transportasi yaitu angkutan kota. Banyak masyarakat yang menggunakan angkutan kota tersebut. Namun, pemerintah sebagai pemberi layanan kurang mampu memenuhi apa saja yang menjadi kebutuhan-kebutuhan masyarakatnya. Fenomena sopir angkutan kota yang ugal-ugalan dan kondisi kendaraan tidak layak jalan merupakan pemandangan umum di Kota Makassar. Berdasarkan Data Dinas Perhubungan Kota Makassar, Kota Makassar memiliki 25 trayek angkutan kota dengan jumlah 5.069 kendaraan. Hal ini menimbulkan persaingan sesama angkutan kota yang ada karena banyak trayek jalur yang sama. Selain itu, pengguna kendaraan pribadi semakin lama semakin meningkat.

Persaingan tersebut yang kemudian membuat pendapatan sopir angkutan kota di Kota Makassar berpengaruh, karena pelayanan angkutan kota dan banyaknya kendaraan pribadi sehingga jasa di bidang angkutan kota kurang begitu diminati. penurunan minat pengguna angkutan umum mikrolet di Kota makassar adalah faktor wujud fisik seperti: kebersihan, kenyamanan serta fasilitas angkutan umum yang nyaman selama dalam perjalanan masih menjadi pertimbangan masyarakat untuk menggunakan angkutan umum (Maryam, 2019). Angkutan umum (pete-pete) memberikan harga atau tarif flat yang relatif lebih murah, tetapi waktu tempuh yang relatif lebih lama. Hal inilah yang membuat taksi menjadi moda transportasi umum yang banyak digunakan oleh masyarakat pada segmen kelas menengah ke atas (Narwis, 2017).

Sejak beroperasinya angkutan berbasis online di Kota Makassar pada tahun 2016 dan mendapat respon baik dari masyarakat. Menurut (Harish \& Wardhana, 2016) enam faktor yang menjadi preferensi konsumen dalam menggunakan layanan transportasi online, antara lain: kenyamanan, kecepatan, kepercayaan, kepraktisan, keamanan dan tarif. Adanya transportasi berbasis online mempengaruhi penggunaan angkutan umum di Kota Makassar, terlihat dari semakin meningkatnya pengguna angkutan online dan menimbulkan konflik antara angkutan kota dan angkutan online.

Berdasarkan fakta empiris yang telah dijelaskan diatas, terlihat bahwa pada dasarnya masyarakat yang berada di Kota Makassar memiliki intensitas pergerakan yang sangat tinggi. Untuk memenuhi kebutuhan pergerakan sehari - hari, masyarakat Kota Makassar dapat menggunakan moda transportasi: transportasi pribadi dan transportasi publik. Fakta dilapangan menjelaskan bahwa masyarakat pengguna transportasi umum, banyak yang mengeluhkan akan layanan angkutan umum yang digunakan, baik layanan kenyamanan, ketepatan waktu, dan biaya atau tarif/ ongkos. Berkembangnya angkutan berbasis online jenis mobil seperti grab dan gojek yang awalnya merupakan kompetitor dari angkutan umum/petepete.

Mengidentifikasi karakteristik penggunaan angkutan umum di Kota Malang dengan beberapa aspek, diantaranya: (a) Karakteristik sosial ekonomi yang meliputi jenis kelamin, jenis pekerjaan, usia penumpang, dan tingkat penghasilan dari penumpang (Susilowati, 2011); (b) Karakteristik spasial penumpang yang meliputi asal perjalanan penumpang dan tujuan perjalanan penumpang (Susilowati, 2011); (c) Karakteristik pergerakan yang meliputi, waktu terjadinya pergerakan, dan jarak perjalanan (Tamin, 2000); (d) Karakteristik fasilitas moda transportasi yang meliputi waktu perjalanan dan biaya transportasi (Tamin, 2000); (e) Kualitas pelayanan yang meliputi pengalaman perjalanan, kebersihan, keamanan dan aksesibilitas; dan (f) Kinerja angkutan umum yang meliputi waktu tunggu, kecepatan operasi, jam operasi, dan kapasitas kendaraan.

Karakteristik moda transportasi menurut (Tamin, 2000) terdiri dari 1) Waktu perjalanan; waktu menunggu di tempat pemberhentian bus, waktu berjalan kaki ke tempat pemberhentian bus, waktu selama bergerak; 2) Biaya transportasi (tarif, biaya bahan bakar, dan lain-lain); 3) Ketersediaan ruang dan tarif parkir. Karakteristik moda transportasi menurut beberapa ahli adalah sebagai berikut menurut (Borhan, et al., 2014) faktor-faktor yang mempengaruhi masyarakat untuk menggunakan transportasi umum adalah kualitas pelayanan, dampak lingkungan dan sikap. Berdasarkan penelitian didapatkan bahwa kualitas dan sikap pelayanan memiliki pengaruh positif terhadap perilaku masyarakat untuk menggunakan angkutan umum. Selain itu, penelitian oleh (Borhan, et al., 2014) juga menunjukkan bahwa kualitas layanan dan dampak lingkungan memiliki pengaruh positif terhadap sikap menggunakan angkutan umum. Namun, dampak lingkungan tidak berpengaruh signifikan, positif dan langsung terhadap niat perilaku.

Menurut (Diab, Lierop, \& Geneidy, 2017) faktorfaktor yang mempengaruhi persepsi pengguna angkutan umum dan kepuasan yaitu dengan kualitas pelayanan. Kemudian didapatkan bagi calon pengguna variabel yang lebih penting saat menentukan kualitas yang diharapkan dari angkutan umum adalah waktu tunggu, waktu perjalanan dan tingkat hunian, variabel lain kurang penting saat menentukan layanan transportasi umum yang efisien.

Menurut (Ismail, Hafezi, Nor, \& Ambak, 2012) untuk mengetahui tingkat preferensi penumpang angkutan umum digunakan variabel kualitas pelayanan. Dalam studi tersebut, didapatkan empat atribut yang memiliki hubungan dengan tingkat kepuasan adalah frekuensi, pengalaman perjalanan, keamanan dan waktu tempuh. Selain itu, (Trynopoulos \& Antoniou, 2008) menemukan bahwa peningkatan kualitas pelayanan berfokus pada frekuensi kendaraan, waktu tunggu, dan kebersihan. Kualitas pelayanan adalah ukuran menyeluruh dari karakteristik operasi dan pelayanan yang mempengaruhi penumpang. Kualitas pelayanan dapat memberikan indikator terhadap baik buruknya moda transportasi dalam mengoperasikan kendaraannya.

Oleh karena itu, diperlukan penelitian yang bertujuan untuk menganalisis karakteristik pengguna angkutan umum di Kota Makassar berdasarkan preferensi masyarakat dalam 
menggunakan angkutan umum sebagai alat penunjang transportasi kegiatan sehari-hari untuk memenuhi kebutuhannya terhadap penggunaan angkutan umum di Kota Makassar.

\section{Metode Penelitian}

a. Jenis Penelitian

Penelitian tentang karakteristik pengguna angkutan umum di Kota Makassar merupakan jenis penelitian kuantitatif. Penelitian kuantitatif merupakan suatu pendekatan dalam melakukan penelitian yang memusatkan perhatian pada fenomena atau gejala yang ada di kehidupan manusia yang dinamakan variabel, kemudian hubungan variabel- variabel dianalisis menggunakan teori yang objektif (Darmawan, 2014).

\section{b. Lokasi Penelitian}

Pemilihan lokasi di Kota Makassar sebagai daerah kajian karena terjadi ketidakmerataan pengguna angkutan umum di Kota Makassar baik angkutan umum konvensional maupun yang berbasis online yang mengakibatkan munculnya konflik. Hal ini sesuai dengan data bahwa jumlah angkutan kota yaitu 4.550. Jumlah Angkutan Kota di Kota Makassar mengalami penurunan di setiap tahun, tidak banyak hanya sekitar 5-10 kendaraan di setiap tahunnya. (Dinas Perhubungan Kota Makassar, 2017).

\section{c. Lingkup Penelitian}

Ruang lingkup materi yang akan dibahas dalam penelitian ini adalah angkutan umum di Kota Makassar yang terdiri dari Angkutan konvensional (angkutan kota) dan Angkutan berbasis online. Untuk melihat preferensi masyarakat dalam menggunakan angkutan umum terhadap penggunaan angkutan umum, variabel yang digunakan adalah menggunakan pendekatan variabel pemilihan moda dan beberapa teori lain terkait faktor yang mempengaruhi seseorang menggunakan angkutan umum

\section{d. Variabel Penelitian}

Variabel penelitian dari karakteristik penggunaan angkutan umum, peneliti menggunakan seluruh indikator yang ada karena seluruh indikator memiliki peran penting untuk mengetahui bagaimana karakteristik dari masingmasing indikator tersebut. Penelitian ini menggunakan pendekatan pemilihan moda dengan 3 (tiga) faktor yang mempengaruhi pemilihan moda tersebut yaitu ciri pengguna, ciri pergerakan, ciri fasilitas moda transportasi dan beberapa variabel terkait kualitas pelayanan.

a. Karakteristik sosial ekonomi yang meliputi jenis kelamin, jenis pekerjaan, usia penumpang, dan tingkat penghasilan dari penumpang (Susilowati, 2011).

b. Karakteristik spasial penumpang yang meliputi asal perjalanan penumpang dan tujuan perjalanan penumpang (Susilowati, 2011).

c. Karakteristik pergerakan yang meliputi, waktu terjadinya pergerakan, dan jarak perjalanan (Tamin, 2000).

d. Karakteristik fasilitas moda transportasi yang meliputi waktu perjalanan dan biaya transportasi (Tamin, 2000). e. Kualitas pelayanan yang meliputi pengalaman perjalanan, kebersihan, keamanan dan aksesibilitas.

f. Kinerja angkutan umum yang meliputi waktu tunggu, kecepatan operasi, jam operasi, dan kapasitas kendaraan.

g. Populasi dan Sampel

Menurut Sugiyono (2014), sampel adalah bagian dari jumlah dan karakteristik yang dimiliki oleh populasi. Sampel adalah sebagian dari populasi yang dapat mewakili seluruh populasi. Penarikan sampel dalam penelitian ini menggunakan metode Accidental Sampling. Menurut Sugiyono (2009) accidental Sampling adalah teknik penentuan sampel berdasarkan kebetulan, yaitu pengguna yang secara kebetulan/insidental mengisi kuesioner melalui google form yang dibagikan. Survai ini dimaksudkan untuk mendapatkan informasi mengenai kualitas pelayanan angkutan dengan beberapa pengukuran kepuasan berdasarkan sistem minimal angkutan perkotaan dan aturan yang diperintahkan oleh pemerintah, serta mengidentifikasi beberapa alternatif pendorong untuk menggunakan angkutan umum.

Penentuan sampel adalah berdasarkan Makassar yang digunakan dalam penelitian. Makassar yaitu wilayah generalisasi yang terdiri atas obyek/subyek yang mempunyai kualitas dan karakteristik tertentu yang ditetapkan oleh peneliti untuk dipelajari dan kemudian ditarik kesimpulannya. Makassar dalam penelitian ini adalah seluruh penguna angkutan konvensional dan angkutan berbasis online di Kota Makassar. Sedangkan sampel yaitu bagian dari jumlah dan karakteristik yang dimiliki oleh Makassar tersebut (Sugiyono, 2014). Namun, Makassar dalam penelitian ini tidak diketahui jumlahnya, sehingga digunakan rumus untuk menghitung sampel dengan Makassar yang tidak diketahui yaitu dengan menggunakan rumus Sample Linear Time Function. Metode Linier Time Function adalah penentuan jumlah sampel berdasarkan estimasi kendala waktu. Besarnya jumlah sampel (n) yang diambil menggunakan rumus perhitungan sebagai berikut :

$$
n=\frac{T-t 0}{t 1}
$$

Keterangan :

$\mathrm{n} \quad$ : jumlah sampel yang terpilih

$\mathrm{T} \quad$ : waktu yang tersedia bagi pelaksanaan penelitian

: 14 hari x 24 jam $=336 \mathrm{jam} /$ minggu

t0 : waktu tetap lamanya survey

: $10 \mathrm{jam} /$ hari x 14 hari $=238 \mathrm{jam} / \mathrm{minggu}$

t1 : waktu yang digunakan bagi responden untuk mengisi kuisioner

: 15 menit $=0,25$ jam

$$
\begin{gathered}
n=\frac{T-t 0}{t 1}=\frac{336-238}{0,25}=392 \text { responden } \\
=400 \text { responden (dibulatkan) }
\end{gathered}
$$

e. Teknik Pengumpulan Data

a) Teknik survei primer yang digunakan dalam penelitian ini adalah berupa pembagian kuisioner kepada masyarakat di wilayah studi. Kuisioner merupakan teknik pengambilan data dengan menyampaikan sejumlah pertanyaan tertulis untuk dijawab secara tertulis oleh responden 
yang bertujuan untuk mengumpulkan informasi tertentu. Responden dari kuisioner ini adalah masyarakat Kota Makassar yang akan menjadi pengguna angkutan umum. Tujuan dari pengumpulan kuisioner dalam penelitian ini adalah untuk memperoleh informasi yang berkaitan dengan variabel penelitian seperti karakteristik sosial-ekonomi masyarakat, karakteristik spasial, ciri pergerakan, ciri fasilitas moda, ciri kota dan kualitas pelayanan. Seluruh variabel yang digunakan dalam penelitian ini menggunakan metode pengambilan data berupa kuisioner yang dibagikan dan dijawab langsung oleh responden yaitu masyarakat Kota Makassar. Hal ini karena seluruh variabel yang digunakan merupakan data dari masing-masing responden, sehingga data tersebut didapatkan dari jawaban masing-masing responden, bukan hasil dari pengamatan.

b) Survei sekunder yang dilakukan pada penelitian ini adalah dengan menggunakan studi literatur. Studi literatur yang digunakan dalam penelitian ini meliputi data sekunder yang telah tersedia di lembaga atau instansi terkait, buku-buku referensi maupun peraturan-peraturan atau kebijakan yang terkait dengan transportasi yang meliputi karakteristik pengguna angkutan umum, karakteristik perjalanan angkutan umum dan teori-teori yang berkaitan dengan preferensi pengguna. Teori-teori tersebut dapat dijadikan landasan dalam menjalankan penelitian, sebelum melakukan survei lapangan maupun menganalisa data yang didapat setelah melakukan observasi lapangan.

\section{f. Teknik Analisis Data}

Penelitian ini menggunakan dua jenis analisis (1) analisis deskriptif khususnya bagi variabel yang bersifat kualitatif dan (2) analisis verifikatif berupa pengujian hipotesis dengan menggunakan uji statistik. Analisis deskriptif digunakan untuk melihat faktor penyebab sedangkan analisis kuantitatif menitikberatkan dalam pengungkapan perilaku variabel penelitian. Dengan menggunakan kombinasi metode analisis tersebut dapat diperoleh generalisasi yang bersifat komprehensif.

Analisis deskriptif bertujuan mengubah kumpulan data mentah menjadi mudah dipahami dalam bentuk informasi yang lebih ringkas. Analisis deskriptif dapat digunakan untuk mencari kuatnya hubungan antara variabel melalui analisis korelasi dan membuat perbandingan dengan membandingkan rata-rata data sampel atau
Makassar tanpa perlu diuji signifikansinya (Sugiyono, 2010).

\section{Hasil dan Pembahasan}

\subsection{Karakteristik Angkutan Kota dan Angkutan Berbasis Online di Kota Makassar}

a. Angkutan Kota

Angkutan umum di Kota Makassar masih digunakan oleh sebagian penduduk untuk melakukan pergerakan. Angkutan umum di Kota Makassar terdiri dari angkutan kota (mikrolet), taxi, dan becak.. Angkutan umum yang dibahas dalam penelitian ini adalah angkutan kota. Adapun jumlah dan panjang armada trayek angkutan umum

Pola pelayanan angkutan umum kota yang mengikuti pola penyebaran aktifitas dan penggunaan lahan kota secara radial menyebabkan beberapa ruas jalan yang dilalui trayek angkutan tersebut akan saling tumpang tindih dan padat lalulintas yang cenderung menjadikan trayek gemuk.

b. Angkutan Berbasis Online

Sejak tahun 2016, terdapat bisnis transportasi berbasis online yang masuk ke Indonesia termasuk di Kota Makassar. Transportasi online adalah suatu aktivitas penawaran layanan perpindahan dari suatu tempat ke tempat lain dengan menggunakan media pengangkutan yang terkendali oleh suatu system yang terhubung dengan perangkat telekomunikasi. Transportasi online ini berupa jasa transportasi informal ojek yang bertransformasi menjadi ojek professional dengan didukung oleh kecanggihan teknologi sehinggga lahirlah transportasi berbasis online. Kecanggihan teknologi yang digunakan oleh perusahaan Go-Jek dan Grab adalah dengan membuat sebuah aplikasi mobile yang dapat dengan mudah diunduh di Play Store di Android. Terdapat 2 perusahaan besar transportasi online di Kota Makassar yaitu Go-Jek dan Grab. Perusahaan-perusahaan transportasi online ini berusaha menawarkan hal-hal yang tidak dimiliki oleh transportasi konvensional di Kota Makassar seperti kecepatan, keamanan, kenyamanan serta transportasi online ini tidak hanya berupa kendaraan beroda 2 namun juga kendaraan beroda 4 (Harish \& Wardhana, 2016).

4.2. Karakteristik Pengguna Angkutan Kota dan Angkutan Berbasis Online di Kota Makassar

a. Karakteristik Sosial Ekonomi Pengguna Angkutan Kota dan Angkutan Berbasis Online

Karakteristik sosial ekonomi pengguna Angkutan Umum dan Angkutan Berbasis Online berdasarkan jenis kelamin, jenis pekerjaan, usia dan tingkat penghasilan di Kota Makassar adalah seperti pada Tabel 1 berikut ini:

Tabel 1 Karakteristik Sosial Ekonomi

\begin{tabular}{|c|c|c|c|c|c|}
\hline \multirow{2}{*}{$\begin{array}{c}\text { Karakteristik Sosial } \\
\text { Ekonomi }\end{array}$} & \multirow{2}{*}{ Item } & \multicolumn{2}{|c|}{ Angkutan Umum (pete-pete) } & \multicolumn{2}{|c|}{ Angkutan Berbasis Online } \\
\hline & & Jumlah & Presentase & Jumlah & Persentase \\
\hline \multirow[t]{2}{*}{ Jenis Kelamin } & $\mathrm{L}$ & 90 & $45 \%$ & 94 & $47 \%$ \\
\hline & $\mathrm{P}$ & 110 & $55 \%$ & 106 & $53 \%$ \\
\hline \multirow[t]{6}{*}{ Jenis Pekerjaan } & Pegawai Negeri Sipil & 11 & $5,5 \%$ & 17 & $8,5 \%$ \\
\hline & Pegawai Swasta & 32 & $16 \%$ & 22 & $11 \%$ \\
\hline & Pelajar/Mahasiswa & 17 & $8,5 \%$ & 90 & $45 \%$ \\
\hline & Ibu Rumah Tangga & 28 & $14 \%$ & 15 & $7,5 \%$ \\
\hline & Wiraswasta & 19 & $9,5 \%$ & 20 & $10 \%$ \\
\hline & Pedagang & 30 & $15 \%$ & 13 & $6,5 \%$ \\
\hline
\end{tabular}


ISSN 2656-8705

URSJ 3(2): 83-94, Juni 2021

\begin{tabular}{|c|c|c|c|c|c|}
\hline & Buruh & 49 & $24,5 \%$ & 10 & $5 \%$ \\
\hline & Pensiunan & 14 & $7 \%$ & 13 & $6,5 \%$ \\
\hline \multirow[t]{5}{*}{ Usia } & $17-25$ tahun & 21 & $10,5 \%$ & 32 & $16 \%$ \\
\hline & $26-35$ tahun & 35 & $17,5 \%$ & 79 & $39,5 \%$ \\
\hline & $36-45$ tahun & 89 & $44,5 \%$ & 65 & $32,5 \%$ \\
\hline & $46-55$ tahun & 40 & $20 \%$ & 14 & $7 \%$ \\
\hline & 55 tahun keatas & 15 & $7,5 \%$ & 10 & $5 \%$ \\
\hline \multirow[t]{6}{*}{ Tingkat Pendapatan } & $<\operatorname{Rp} 1.000 .000$ & 32 & $16 \%$ & 12 & $6 \%$ \\
\hline & Rp 1.000.001 - Rp 1.499.999 & 39 & $19,5 \%$ & 20 & $10 \%$ \\
\hline & Rp 1.500.000 - Rp 1.999.999 & 58 & $29 \%$ & 47 & $23,5 \%$ \\
\hline & Rp 2.000.000 - Rp 2.999.999 & 49 & $24,5 \%$ & 69 & $34,5 \%$ \\
\hline & Rp 3.000.000 - Rp 3.999.999 & 15 & $7,5 \%$ & 34 & $17 \%$ \\
\hline & $>\operatorname{Rp} 4.000 .000,-$ & 7 & $3,5 \%$ & 18 & $9 \%$ \\
\hline
\end{tabular}

Sumber: Analisa Data, 2021

1) Jenis Kelamin

Karakteristik sosial ekonomi pengguna Angkutan Umum dan Angkutan Berbasis Online berdasarkan jenis kelamin di Kota Makassar dapat dilihat pada Gambar 1 berikut ini:

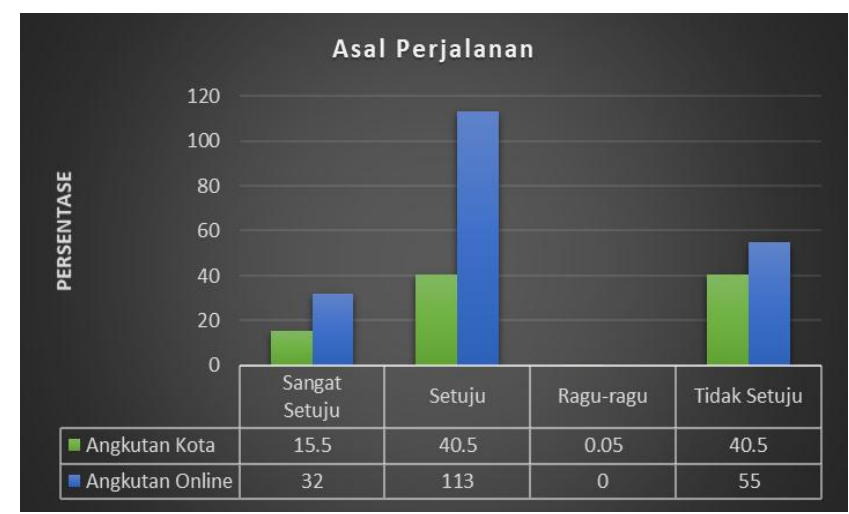

Gambar 1 Karakteristik Sosial Ekonomi Berdasarkan Jenis Kelamin

Berdasarkan Gambar 1 dapat diketahui bahwa pengguna Angkutan Umum maupun Angkutan Online di Kota Makassar di dominasi oleh perempuan, yaitu $55 \%$ untuk Angkutan Umum dan 53\% untuk Angkutan Online. Sedangkan jumlah pengguna laki-laki yaitu $45 \%$ untuk Angkutan Kota dan $47 \%$ untuk Angkutan Online.

2) Jenis Pekerjaan

Karakteristik sosial ekonomi pengguna Angkutan Umum dan Angkutan Berbasis Online berdasarkan jenis pekerjaan di Kota Makassar dapat dilihat pada Gambar 2 berikut ini:

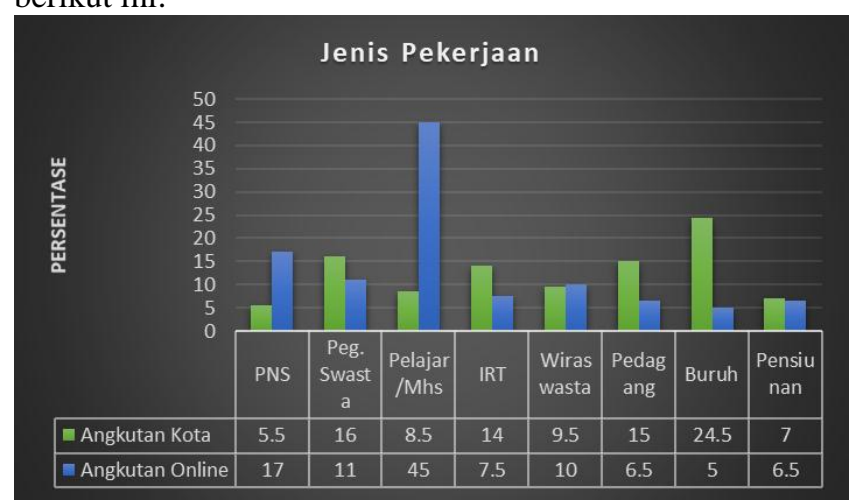

Gambar 2 Karakteristik Sosial Ekonomi Berdasarkan Jenis Pekerjaan
Berdasarkan Gambar 2 dapat diketahui bahwa pengguna Angkutan Umum dan Angkutan Online paling banyak adalah pelajar dan mahasiswa yaitu sebanyak $45 \%$ untuk Angkutan Online tetapi hanya 8,5\% untuk pengguna angkutan kota pete-pete. Ada beberapa kelompok masyarakat yang juga menggunakan angkutan umum maupun angkutan online namun presentasenya kecil, seperti Padagang dan pensiunan hanya 6,5\%, Buruh 5\% untuk Angkutan Online dan PNS 5,5\% untuk Angkutan Umum. Berdasarkan survey primer yang dilakukan, masyarakat dengan rata-rata umur $>30$ tahun atau dalam kategori usia dewasa dan bekerja, sudah tidak pernah menggunakan kendaraan umum, hal ini karena sebagian besar dari mereka lebih menggunakan kendaraan pribadi sehingga hanya dalam presentase kecil yang memilih menggunakan angkutan umum. Sedangkan sebanyak $90 \%$ pelajar dan mahasiswa memilih menggunakan angkutan online karena beberapa alasan seperti cepat dan terjangkau.

3) Usia

Karakteristik sosial ekonomi pengguna Angkutan Umum dan Angkutan Berbasis Online berdasarkan usia di Kota Makassar adalah seperti pada Gambar 3 berikut ini:

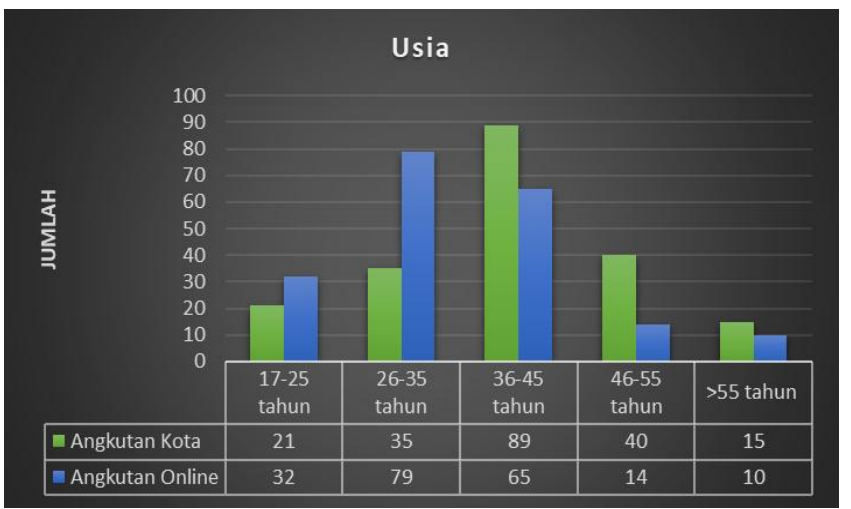

Gambar 3 Karakteristik Sosial Ekonomi Berdasarkan Usia

Berdasarkan Gambar 3 dapat diketahui bahwa pengguna Angkutan Umum dan Angkutan Online paling banyak adalah penduduk dengan rentang antara usia 26-35 tahun untuk pengguna Angkutan Online dan rentang usia 36-45 tahun untuk pengguna Angkutan Umum. Hal ini sesuai dengan Gambar 3 yaitu pekerjaan pengguna Angkutan Umum dan Angkutan Online paling banyak adalah pelajar dan mahasiswa. Hal ini berkaitan dengan karakteristik jenis pekerjaan, bahwa seseorang yang sudah 
bekerja cenderung lebih memilih menggunakan kendaraan pribadi daripada angkutan umum.

4) Tingkat Pendapatan

Karakteristik sosial ekonomi pengguna Angkutan Umum dan Angkutan Berbasis Online berdasarkan Tingkat Pendapatan di Kota Makassar juga dapat dilihat pada Gambar 4 berikut ini:

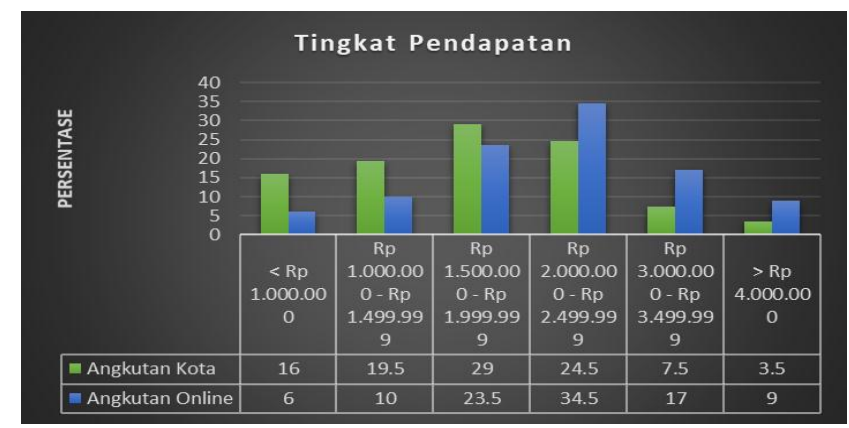

Gambar 4 Karakteristik Sosial Ekonomi Berdasarkan Tingkat Pendapatan
Berdasarkan Gambar 4 dapat diketahui bahwa penghasilan pengguna Angkutan Umum dan Angkutan Online paling banyak adalah berkisar antara $\mathrm{Rp}$ 2.000.000,00 sampai Rp 2.999.999,00 yaitu 24,5\% untuk Angkutan Umum dan 34,5\% untuk Angkutan Online dan Rp 1.500.000 sampai Rp 1.999.999,00 yaitu sebanyak 29\% untuk Angkutan Umum dan 23,5\% untuk Angkutan Online. Angkutan kota dan angkutan online saat ini cukup dapat digunakan oleh penduduk Kota Makassar dengan penghasilan kecil maupun besar.

b. Karakteristik Spasial Pengguna Angkutan Kota dan Angkutan Berbasis Online

Karakteristik spasial pengguna Angkutan Kota dan Angkutan Berbasis Online berdasarkan asal perjalanan dan tujuan perjalanan responden di Kota Makassar adalah seperti pada Tabel 2 berikut ini:

Tabel 2 Karakteristik Spasial

\begin{tabular}{|c|c|c|c|c|c|}
\hline \multirow{2}{*}{ Karakteristik Spasial } & \multirow{2}{*}{ Item } & \multicolumn{2}{|c|}{ Angkutan Kota } & \multicolumn{2}{|c|}{ Angkutan Berbasis Online } \\
\hline & & Jumlah & Presentase & Jumlah & Presentase \\
\hline \multirow[t]{5}{*}{ Asal Perjalanan } & Rumah & 110 & $55 \%$ & 74 & $37 \%$ \\
\hline & Sekolah/Kampus & 72 & $36 \%$ & 53 & $26,5 \%$ \\
\hline & Tempat Bekerja & 12 & $6 \%$ & 28 & $14 \%$ \\
\hline & Pusat Perbelanjaan & 2 & $1 \%$ & 7 & $3,5 \%$ \\
\hline & Lain-lain & 4 & $2 \%$ & 38 & $19 \%$ \\
\hline \multirow[t]{5}{*}{ Tujuan Perjalanan } & Rumah & 57 & $28,5 \%$ & 45 & $22,5 \%$ \\
\hline & Sekolah/Kuliah & 35 & $17,5 \%$ & 78 & $39 \%$ \\
\hline & Bekerja & 67 & $30,5 \%$ & 16 & $8 \%$ \\
\hline & Berbelanja & 31 & $15,5 \%$ & 26 & $13 \%$ \\
\hline & Lain-lain & 16 & $8 \%$ & 35 & $17,5 \%$ \\
\hline
\end{tabular}

Sumber: Analisa Data, 2021

1) Asal Perjalanan

Karakteristik spasial pengguna Angkutan Kota dan Angkutan Berbasis Online berdasarkan asal mula melakukan perjalanan di Kota Makassar dapat juga dilihat pada Gambar 5 berikut ini:

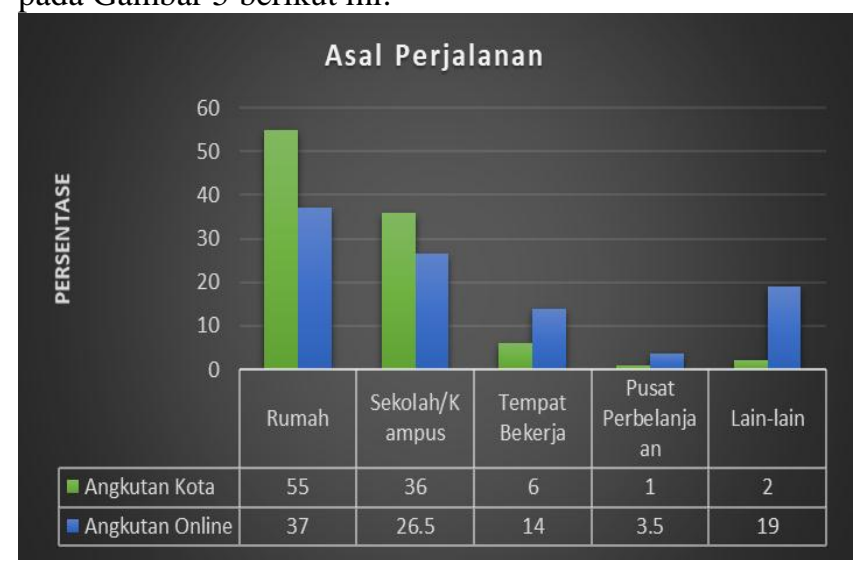

Gambar 5 Karakteristik Spasial Berdasarkan Asal Perjalanan

Berdasarkan Gambar 5 dapat diketahui bahwa asal mula pengguna Angkutan Kota dan Angkutan Online melakukan perjalanan paling banyak adalah dari rumah sebesar 55\% untuk angkutan kota dan 37\% untuk angkutan online. Sedangkan dari sekolah atau kampus masing- masing sebesar $36 \%$ dan 26,5\%. Hal ini karena asal mula mereka melakukan perjalanan yaitu rumah atau sekolah dilewati oleh angkutan kota maupun angkutan online. Asal perjalanan angkutan online lebih bervariasi karena angkutan online lebih mudah mencapai lokasi tertentu dan fleksibel bisa menjemput dimana saja.

2) Tujuan Perjalanan

Karakteristik spasial pengguna Angkutan Kota dan Angkutan Berbasis Online berdasarkan tujuan melakukan perjalanan di Kota Makassar juga dapat dilihat pada Gambar 6 berikut ini:

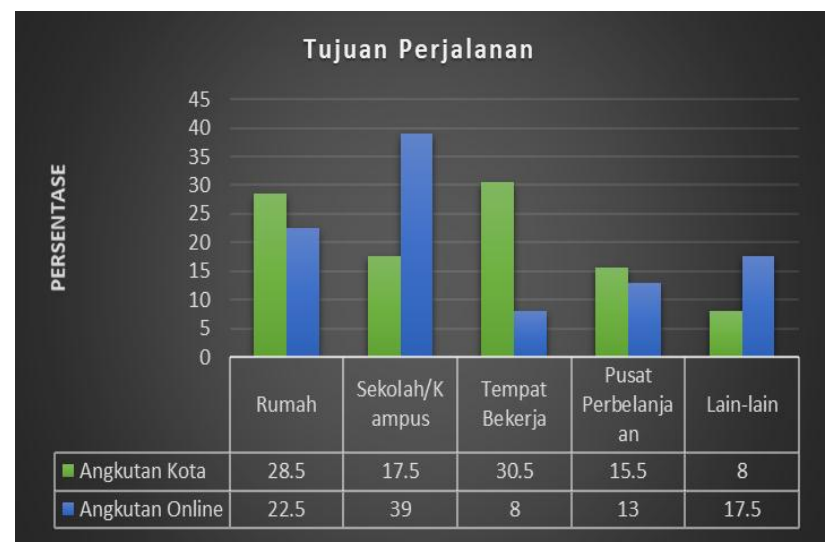

Gambar 6 Karakteristik Spasial Berdasarkan Tujuan Perjalanan 
Berdasarkan Gambar 6 dapat diketahui bahwa tujuan pengguna melakukan perjalanan dengan menggunakan Angkutan Kota dan Angkutan Online adalah paling banyak untuk pergi ke sekolah/kuliah, yaitu dengan 17,5\% untuk Angkutan Kota dan 39\% untuk Angkutan Online. Tujuan perjalanan yang lain adalah untuk pulang kerumah sebesar 28,5\% untuk Angkutan Kota dan 22,5\% untuk Angkutan Online. Pengguna menggunakan angkutan online untuk mencapai tujuan perjalanan karena terburu-buru, cepat, mudah dan fleksibel. Sedangkan menggunakan angkutan kota karena, tujuan perjalanan mereka dilewati oleh angkutan kota dan karena faktor kebiasaan. c. Ciri Pergerakan Pengguna Angkutan Kota dan Angkutan Berbasis Online

Ciri pergerakan pengguna Angkutan Kota dan Angkutan Berbasis Online berdasarkan waktu terjadinya perjalanan dan jarak perjalanan responden di Kota Makassar adalah seperti pada Tabel 3 berikut ini:

Tabel 3 Ciri Pergerakan

\begin{tabular}{|c|c|c|c|c|c|}
\hline \multirow{2}{*}{ Ciri Peregerakan } & \multirow{2}{*}{ Item } & \multicolumn{2}{|c|}{ Angkutan Kota } & \multicolumn{2}{|c|}{ Angkutan Berbasis Online } \\
\hline & & Jumlah & Presentase & Jumlah & Presentase \\
\hline \multirow[t]{4}{*}{ Waktu terjadinya perjalanan } & Pagi & 43 & $21,5 \%$ & 58 & $29 \%$ \\
\hline & Siang & 95 & $47,5 \%$ & 51 & $25,5 \%$ \\
\hline & Sore & 59 & $59,5 \%$ & 74 & $37 \%$ \\
\hline & Malam & 3 & $1,5 \%$ & 17 & $8,5 \%$ \\
\hline \multirow[t]{4}{*}{ Jarak Perjalanan } & $<2 \mathrm{~km}$ & 46 & $23 \%$ & 32 & $16 \%$ \\
\hline & $2,1 \mathrm{~km}-4 \mathrm{~km}$ & 98 & $49 \%$ & 81 & $40,5 \%$ \\
\hline & $4,1 \mathrm{~km}-6 \mathrm{~km}$ & 40 & $20 \%$ & 62 & $31 \%$ \\
\hline & $>6 \mathrm{~km}$ & 16 & $8 \%$ & 25 & $12,5 \%$ \\
\hline
\end{tabular}

Sumber: Analisa Data, 2021

1) Waktu Terjadinya Pergerakan

Ciri pergerakan pengguna Angkutan Kota dan Angkutan Berbasis Online berdasarkan waktu terjadinya perjalanan di Kota Makassar juga dapat dilihat pada Gambar 7 berikut ini:

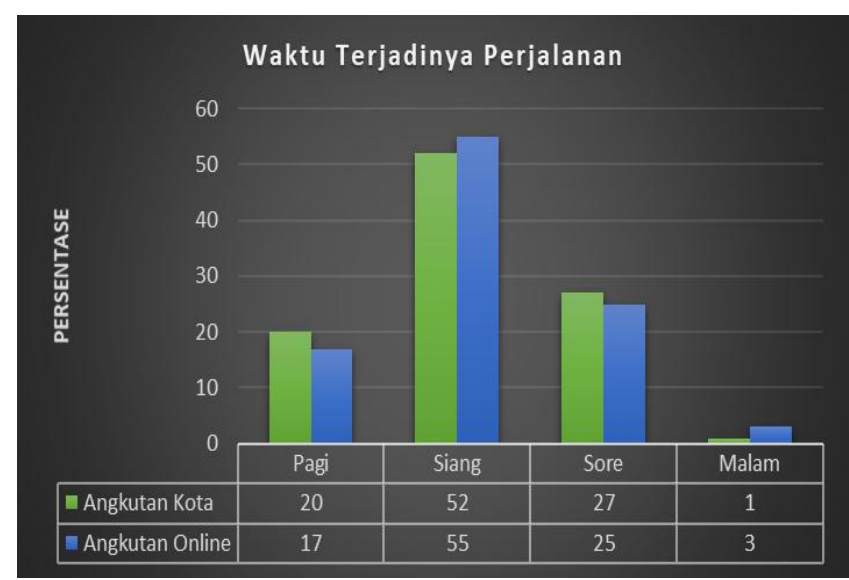

Gambar 7 Ciri Pergerakan Berdasarkan Waktu Terjadinya Perjalanan

Berdasarkan Gambar 7 dapat diketahui bahwa masyarakat Kota Makassar paling banyak melakukan perjalanan dengan menggunakan Angkutan Kota adalah pada waktu sore sebesar 27\%, sedangkan Angkutan Online paling banyak pada waktu siang sebesar 55\%. Masyarakat banyak menggunakan angkutan umum di pagi dan sore hari karena pengguna tertinggi angkutan umum adalah pelajar dan mahasiswa yang mayoritas memulai kegiatan di pagi hari dan berakhir pada sore hari, sehingga penggunaan angkutan umum tertinggi terjadi pada kedua waktu tersebut. Pengguna dengan kategori usia dewasa menggunakan angkutan kota karena lebih mudah, pengguna yang menggunakan angkutan kota di pagi hari dan siang hari karena alasan tidak macet, dan sisanya karena faktor kebiasaan. Sedangkan pengguna angkutan online mengunakan angkutan online hampir di seluruh bagian waktu karena alasan macet dan agar lebih cepat.

2) Jarak Perjalanan

Ciri pergerakan pengguna Angkutan Kota dan Angkutan Berbasis Online berdasarkan jarak perjalanan di Kota Makassar juga dapat dilihat pada Gambar 8 berikut ini:

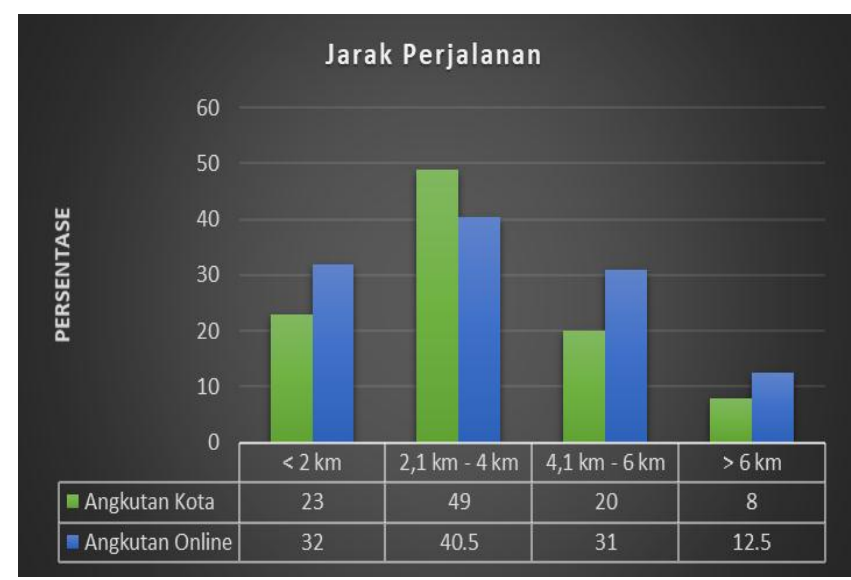

Gambar 8 Ciri Pergerakan Berdasarkan Jarak Perjalanan

Berdasarkan Gambar 8 dapat diketahui bahwa masyarakat pengguna Angkutan Kota maupun Angkutan Online melakukan perjalanan paling banyak dengan jarak 2 $\mathrm{km}-4 \mathrm{~km}$ yaitu masing-masing sebesar $49 \%$ untuk Angkutan Kota dan 40,5\% untuk Angkutan Online. Walaupun jarak perjalanan responden dalam menggunakan angkutan kota dan angkutan online tertinggi pada $2 \mathrm{~km}-4$ $\mathrm{km}$, namun Angkutan kota cenderung digunakan masyarakat untuk perjalanan dalam jarak dekat karena grafiknya semakin menurun, sedangkan angkutan online 
digunakan masyarakat baik jarak dekat maupun jarak jauh karena cepat dan fleksibel.

d. Ciri Fasilitas Moda Pengguna Angkutan Kota dan Angkutan Berbasis Online

Ciri fasilitas moda pengguna Angkutan Kota dan Angkutan Berbasis Online berdasarkan waktu perjalanan dan biaya transportasi responden di Kota Makassar adalah seperti pada Tabel 4 berikut ini:

Tabel 4 Ciri Fasilitas Moda Berdasarkan Waktu tempuh

1) Waktu Perjalanan

\begin{tabular}{|c|c|c|c|c|}
\hline \multirow{2}{*}{ Waktu } & \multicolumn{2}{|c|}{ Angkutan Kota } & \multicolumn{2}{|c|}{ Angkutan Berbasis Online } \\
\hline & Jumlah & Presentase & Jumlah & Presentase \\
\hline$<15$ menit & 16 & $8 \%$ & 40 & $20 \%$ \\
\hline $16-30$ menit & 41 & $20.5 \%$ & 98 & $49 \%$ \\
\hline $31-45$ menit & 79 & $39,5 \%$ & 51 & $20,5 \%$ \\
\hline $46-60$ menit & 27 & $13,5 \%$ & 14 & $8 \%$ \\
\hline$>\quad 60$ menit & 37 & $18,5 \%$ & 7 & $4 \%$ \\
\hline
\end{tabular}

Sumber: Analisa Data, 2021

Ciri fasilitas moda responden Angkutan Kota dan Angkutan Berbasis Online berdasarkan waktu tempuh responden dalam mengggunakan kedua angkutan tersebut di Kota Makassar juga dapat dilihat pada Gambar 9 berikut ini:

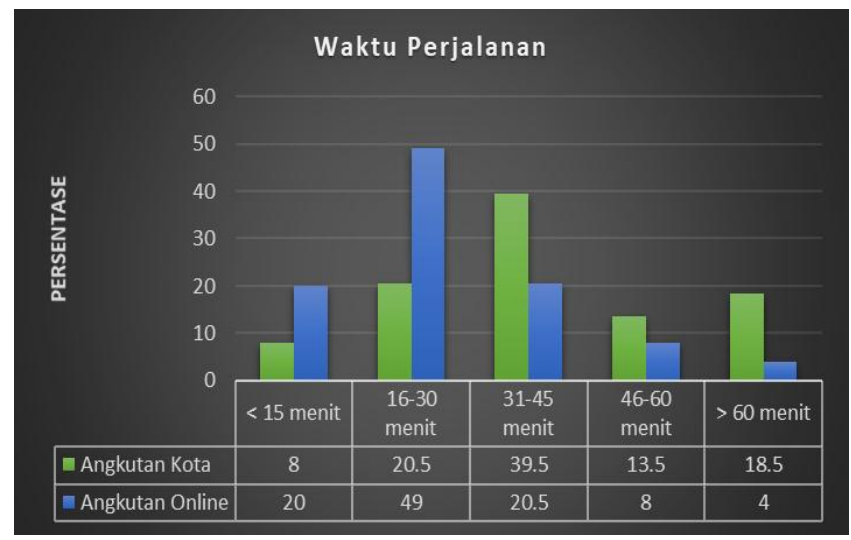

Gambar 9 Ciri Fasilitas Moda Berdasarkan Waktu Perjalanan

Berdasarkan Gambar 9 dapat diketahui bahwa waktu tempuh angkutan berbasis online cenderung lebih singkat apabila dibandingkan dengan angkutan kota, yaitu sebesar $8 \%$ di waktu tempuh < 15 menit dan $20,5 \%$ di waktu tempuh 16-30 menit. Sedangkan angkutan kota cenderung memiliki waktu tempuh yang lebih lama karena sebanyak $39,5 \%$ responden memiliki waktu tempuh yaitu $31-45$ menit. Pada angkutan kota, juga terdapat $8 \%$ responden yang mengatakan memiliki waktu tempuh 46 - 60 menit, hal ini karena kecepatan kendaraan angkutan kota yang lama karena harus mencari penumpang dan sering berhenti menaikkan dan menurunkan penumpang serta tingginya tingkat kemacetan pada titik-titik tertentu di Kota Makassar.

2) Biaya Perjalanan

Ciri Fasilitas Moda pengguna Angkutan Kota dan Angkutan Berbasis Online berdasarkan biaya transportasi di Kota Makassar adalah seperti pada Tabel 4 dan Tabel 5 berikut ini:
Ciri fasilitas moda pengguna Angkutan Kota dan Angkutan Berbasis Online berdasarkan waktu perjalanan di Kota Makassar adalah seperti pada Tabel 4 berikut ini:

\section{- Angkutan Kota}

Tabel 5 Biaya Transportasi Angkutan Kota

\begin{tabular}{lcl}
\multicolumn{1}{c}{ Tarif } & Jumlah & \multicolumn{1}{c}{ Persentase } \\
\hline Rp 5.000,- & 145 & $72,5 \%$ \\
Rp 10.000,- & 48 & $24 \%$ \\
Rp 15.000,- & 7 & $3,5 \%$ \\
\hline
\end{tabular}

Sumber: Analisa Data, 2021

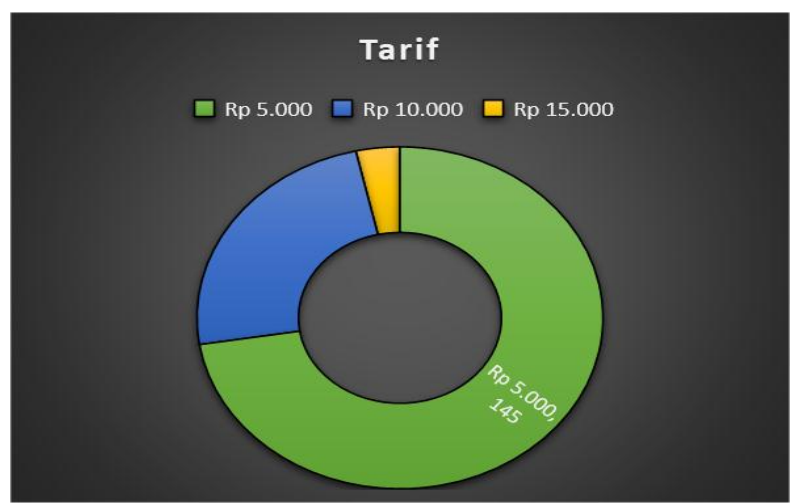

Gambar 10 Ciri Fasilitas Moda Berdasarkan Biaya Transportasi

Berdasarkan Gambar 10 dapat diketahui bahwa tarif untuk sekali perjalanan dengan menggunakan Angkutan Kota adalah Rp 5000,00; Rp 10.000,00; dan Rp 15.000,00, dengan jumlah terbanyak responden menggunakan Angkutan Kota dengan tarif Rp 5000,00 yaitu sebesar 72,5\% karena memang tarif Angkutan Kota untuk saat ini adalah Rp 5000,00. Tetapi untuk pelajar dan jarak tertentu memiliki tarif yang berbeda.

- Angkutan Berbasis Online

Tabel 6 Biaya Transportasi Angkutan Berbasis Online

\begin{tabular}{lcc}
\hline \multicolumn{1}{c}{ Tarif } & Jumlah & Persentase \\
\hline$<$ Rp 5.000,- & 12 & $6 \%$ \\
Rp 5.001 - Rp 10.000,- & 28 & $14 \%$ \\
Rp 10.001, - Rp 20.000,- & 69 & $34,5 \%$ \\
Rp 20.001, - Rp 30.000 & 53 & $26,5 \%$ \\
$>$ Rp 30.000 & 38 & $19 \%$ \\
\hline
\end{tabular}

Sumber: Analisa Data, 2021 


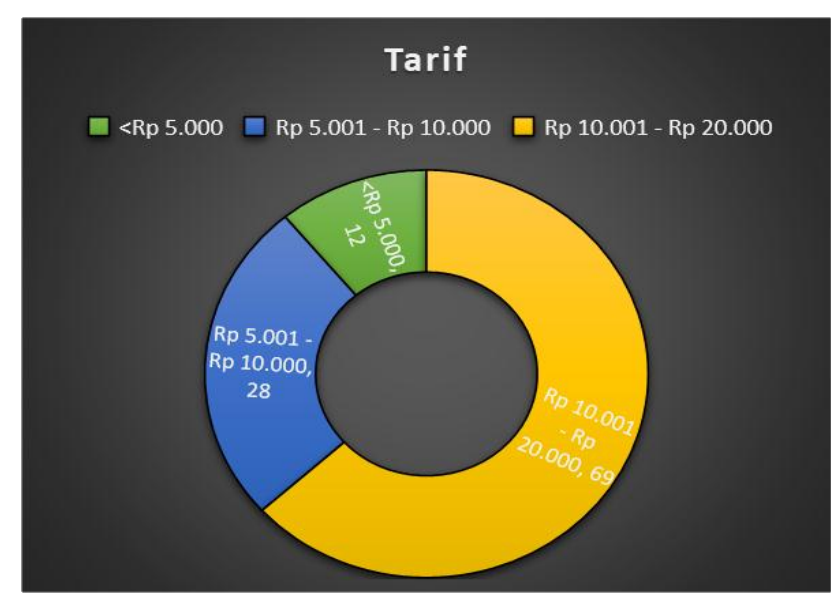

Gambar 11 Ciri Fasilitas Moda Berdasarkan Biaya Transportasi

Berdasarkan Gambar 11 dapat diketahui bahwa masyarakat yang menggunakan Angkutan Online mempunyai tarif yang berbeda dalam satu kali perjalanan. Hal ini karena penentuan tarif Angkutan Online berdasarkan jarak dan kondisi lalu lintas jalan yang akan dilalui sehingga tarifnya berubah-ubah, berbeda dengan Angkutan Kota yang memiliki tarif tetap. Namun berdasarkan Gambar 11 dapat diketahui tarif yang didapatkan masyarakat dalam satu kali perjalanan paling banyak adalah antara Rp 10.000,00 -Rp 20.000,00 yaitu sebesar 34,5\%. Walaupun tarif angkutan online lebih mahal daripada angkutan kota, tetapi penumpang tetap menggunakan angkutan online selain karena cepat, angkutan online sering memberikan promo berupa potongan harga.

e. Kualitas Pelayanan Berdasarkan Pengguna Angkutan

Kota dan Angkutan Berbasis Online

Kualitas pelayanan menurut pengguna berdasarkan pengalaman perjalanan, kebersihan, keamanan dan kenyamanan Angkutan Kota dan Angkutan Berbasis Online di Kota Makassar, seperti berikut ini:

1) Pengalaman Perjalanan

Pengalaman perjalanan masyarakat dalam menggunakan Angkutan Kota dan Angkutan Online dapat dilihat pada Gambar 12 berikut ini:

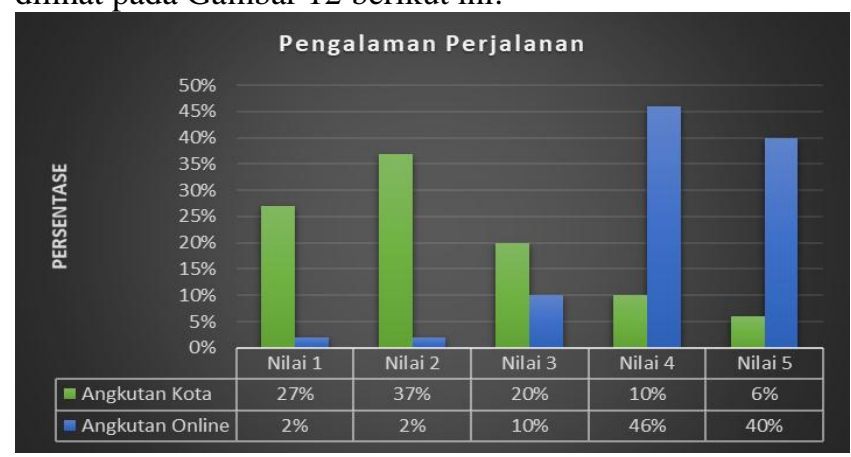

Gambar 12 Penilaian Kualitas Pelayanan Berdasarkan Pengalaman Perjalanan

Berdasarkan Gambar 12 dapat diketahui bahwa penilaian kualitas pelayanan berdasarkan pengalaman masyarakat dalam menggunakan Angkutan Kota dan Angkutan Online, 60\% menilai pengalaman perjalanan angkutan online sangat puas karena diatas nilai rata-rata.
Sedangkan angkutan kota, pengalaman perjalananya dinilai cukup karena banyak yang menilai pengalaman perjalanan pada nilai tengah yaitu 4 , hal tersebut karena selain pengalaman perjalanan yang didapat kurang memuaskan juga karena waktu perjalanan untuk mencapai tujuan memiliki waktu yang lebih lama daripada menggunakan kendaraan pribadi maupun Angkutan Online.

2) Kebersihan

Tingkat kebersihan menurut masyarakat dalam menggunakan Angkutan Kota dan Angkutan Online dapat dilihat pada Gambar 13 berikut ini:

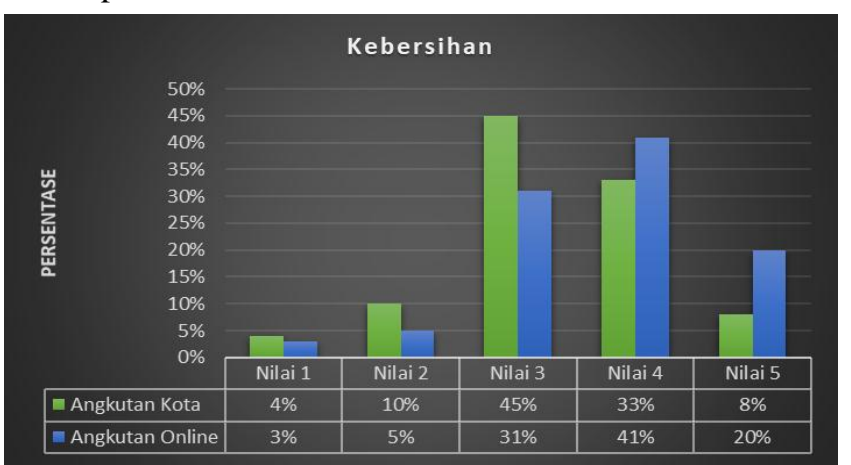

Gambar 13 Penilaian Kualitas Perjalanan Berdasarkan Tingkat Kebersihan

Berdasarkan Gambar 13 diketahui bahwa responden pengguna angkutan online menilai bahwa angkutan online memiliki tingkat kebersihan yang tergolong bersih terlihat dengan nilai kebersihan pada angkutan online $60 \%$ berada diatas nilai tengah. Sedangkan untuk angkutan kota sekitar $40 \%$ menilai angkutan online memiliki tingkat kebersihan dengan nilai diatas 3 , dan terdapat $45 \%$ responden untuk angkutan umum dan $31 \%$ responden untuk angkutan online yang mengatakan bahwa nilai kebersihan angkutan kota adalah 3 yaitu nilai rata-rata keseluruhan yang artinya cukup bersih. Hal ini karena angkutan kota sebenarnya sudah cukup bersih namun beberapa penumpang yang terkadang tidak menjaga kebersihan sehingga mengganggung penumpang yang lain, seperti meninggalkan sampah di dalam angkutan kota

3) Keamanan

Tingkat Keamanan menurut masyarakat dalam menggunakan Angkutan Kota dan Angkutan Online dapat dilihat pada Gambar 14 berikut ini:

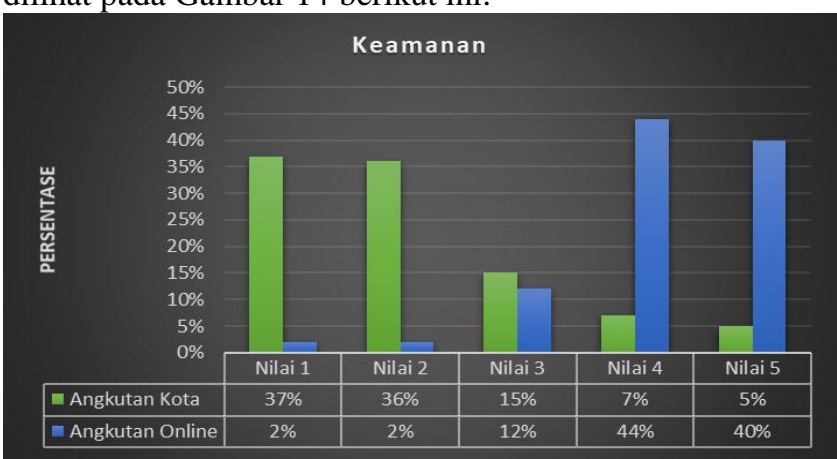

Gambar 14 Penilaian Kualitas Perjalanan Berdasarkan Tingkat Keamanan

Berdasarkan Gambar 14 dapat diketahui bahwa tingkat keamanan adalah hal yang cukup penting. Terlihat dari sedikitnya penilaian responden yang menilai tingkat 
keamanan dibawah nilai rata-rata yaitu 3. Mayoritas responden baik angkutan kota maupun angkutan berbasis online menilai keamanan adalah hal yang penting dengan nilai mereka yang lebih dari $80 \%$ diatas nilai rata-rata yang artinya untuk angkutan kota maupun angkutan berbasis online dinilai sudah tergolong aman untuk digunakan dalam melakukan perjalanan sehari- hari. Penggunna menilai keamanan seperti ketika mereka sampai ke lokasi tujuan dengan selamat, sopir yang tidak ugal-ugalan dan terhindar dari kejahatan.

4) Aksesibilitas

Aksesibilitas menurut masyarakat dalam menggunakan Angkutan Kota dan Angkutan Online dapat dilihat pada Gambar 15 berikut ini:

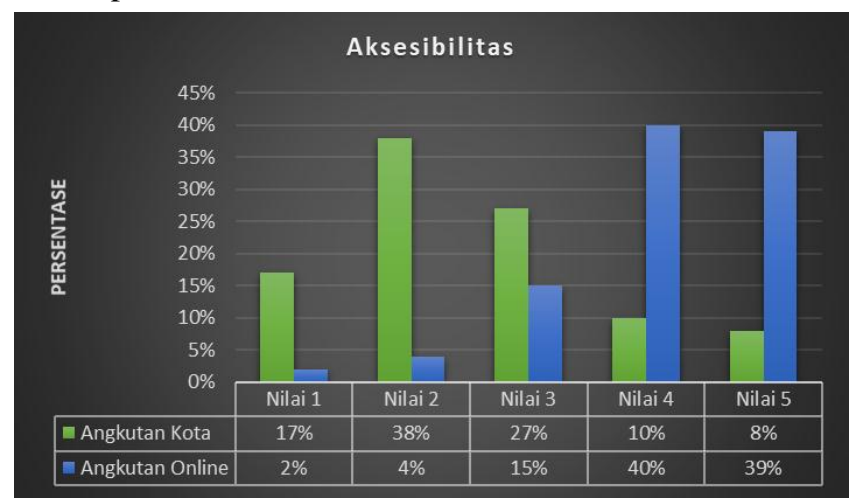

Gambar 15 Kualitas Pelayanan Berdasarkan Aksesibilitas
Aksesibilitas dalam penelitian ini terkait dengan kemampuan angkutan umum untuk mencapai lokasi tertentu. Berdasarkan Gambar 15 dapat diketahui bahwa aksesibilitas pada angkutan kota hanya sebanyak $36 \%$ menilai aksesibilitas diatas nilai rata-rata, dan terdapat $27 \%$ yang menilai tingkat kenyamanan angkutan kota pada nilai rata-rata yaitu 3, sisanya menilai tingkat aksesibilitas angkutan kota masih dibawah nilai rata-rata. Penilaian angkutan kota mayoritas pada nilai tengah kebawah, karena tidak seluruh wilayah di Kota Makassar sudah terlayani oleh angkutan kota. Berbeda halnya dengan angkutan online yaitu $68 \%$ responden memberikan nilai diatas nilai rata-rata karena angkutan online tidak memiliki trayek sehinga dapat menjangkau seluruh wilayah di Kota Makassar.

f. Kinerja Angkutan Umum Berdasarkan Pengguna Angkutan Kota dan Angkutan Berbasis Online

Kinerja angkutan umum menurut pengguna berdasarkan dalam penelitian ini, meliputi waktu tunggu, kecepatan operasi dan jam operasi Angkutan Umum dan Angkutan Berbasis Online di Kota Makassar, seperti berikut ini:

1) Waktu Tunggu

Kinerja Angkutan Umum berdasarkan waktu tunggu masyarakat untuk mendapatkan Angkutan Kota maupun Angkutan Online dapat dilihat pada Tabel 7 dan Gambar 16 berikut ini:

Tabel 7 Kinerja Angkutan Umum Berdasarkan Waktu Tunggu

\begin{tabular}{lcrrr}
\hline \multirow{2}{*}{ Waktu Tunggu } & \multicolumn{2}{c}{ Angkutan Kota } & \multicolumn{2}{c}{ Angkutan Berbasis Online } \\
\cline { 2 - 5 } & Jumlah & Presentase & Jumlah & Presentase \\
\hline$<10$ menit & 26 & $13 \%$ & 120 & $60 \%$ \\
$11-15$ menit & 89 & $44,5 \%$ & 59 & $29 \%$ \\
$16-20$ menit & 75 & $37,5 \%$ & 12 & $6 \%$ \\
$>\quad 20$ menit & 10 & $5 \%$ & 10 & $5 \%$ \\
\hline
\end{tabular}

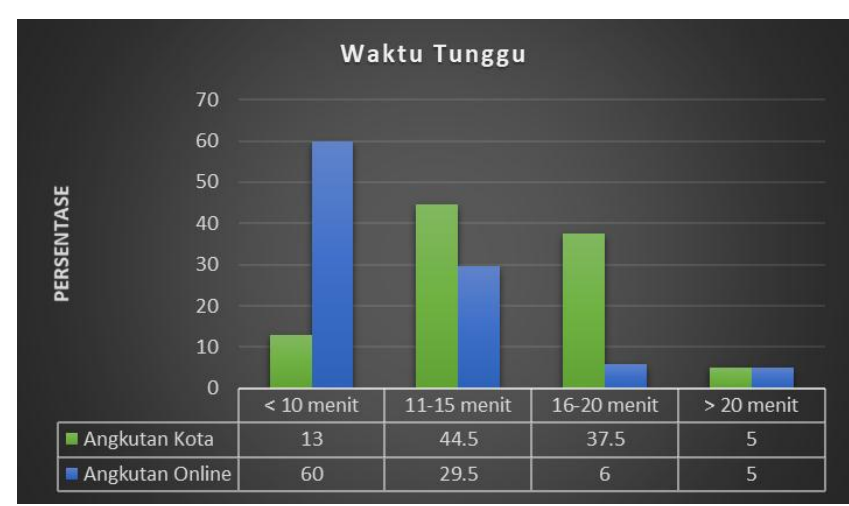

Gambar 16 Kinerja Angkutan Umum berdasarkan Waktu Tunggu
Berdasarkan Gambar 16 dapat diketahui bahwa waktu tunggu angkutan online lebih singkat daripada angkutan kota, terlihat dari mayoritas pengguna angkutan online memiliki waktu tunggu hanya $<10$ menit. Waktu tunggu yang lebih cepat yaitu $<10$ menit, walaupun tidak banyak namun presentase angkutan kota lebih tinggi daripada angkutan online. Sebanyak $45 \%$ responden juga menyatakan memiliki waktu tunggu angkutan kota yang 11-15 menit, dimana beberapa angkutan kota yang memiliki armada dengan trayek yang sama memang mudah didapatkan, sehingga waktu tunggunya.

2) Kecepatan Kendaraan

Kinerja Angkutan Umum berdasarkan kecepatan kendaraan Angkutan Kota dan Angkutan Online dapat dilihat pada Tabel 8 dan Gambar 17 berikut ini:

Tabel 8 Kinerja Angkutan Umum Berdasarkan Kecepatan Kendaraan

\begin{tabular}{lcrrr}
\hline \multicolumn{1}{c}{ Kecepatan } & \multicolumn{2}{c}{ Angkutan Kota } & \multicolumn{2}{c}{ Angkutan Berbasis Online } \\
\cline { 2 - 5 } Operasi & Jumlah & Presentase & Jumlah & Presentase \\
\hline $0-30 \mathrm{~km} / \mathrm{jam}$ & 89 & $44,5 \%$ & 7 & $3,5 \%$ \\
$31-45 \mathrm{~km} / \mathrm{jam}$ & 87 & $43,5 \%$ & 102 & $51 \%$ \\
$46-60 \mathrm{~km} / \mathrm{jam}$ & 24 & $12 \%$ & 71 & $25,5 \%$ \\
$>60 \mathrm{~km} / \mathrm{jam}$ & 0 & $0 \%$ & 17 & $8,5 \%$ \\
\hline
\end{tabular}

Sumber: Analisa Data, 2021 


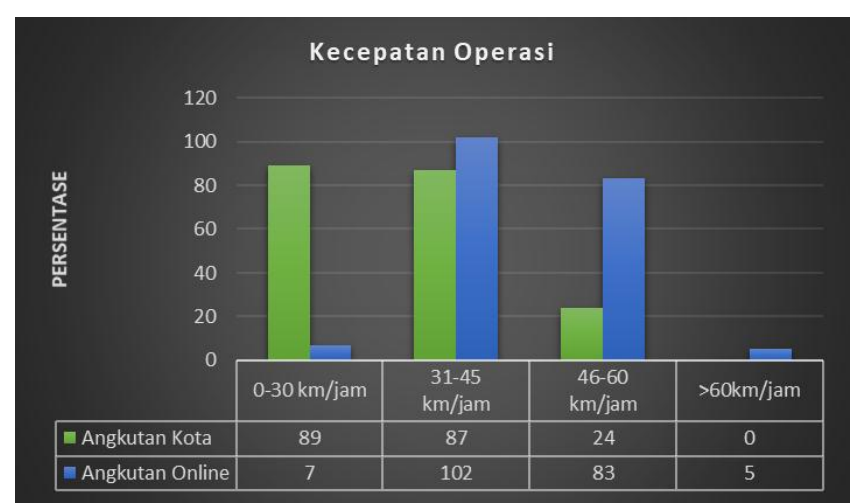

Gambar 17 Kinerja Angkutan Umum Berdasarkan Kecepatan Operasi

Berdasarkan Gambar 18 dapat diketahui bahwa kecepatan kendaraan Angkutan Kota paling banyak adalah pada kecepatan $0-30 \mathrm{~km} / \mathrm{jam}$ sebesar $89 \%$ dan untuk Angkutan Online pada kecepatan 31 - $45 \mathrm{~km} / \mathrm{jam}$ sebesar $102 \%$. Untuk kecepatan paling tinggi yaitu $>60 \mathrm{~km} / \mathrm{jam}$, menurut masyarakat tidak ada Angkutan Kota yang beroperasi dengan kecepatan tersebut, sedangkan untuk Angkutan Online terdapat sebesar 5\%. Kecepatan operasi berhubungan dengan lamanya waktu perjalanan karena semakin cepat kecepatan kendaraan maka akan semakin cepat pula penumpang sampai pada lokasi tujuan. Kecepatan angkutan online yang tergolong cepat berbanding lurus dengan waktu tempuhnya yang singkat. Sedangkan angkutan kota memiliki waktu tempuh yang lebih lama karena selain kecepatan kendaraan yang lebih lambat, juga karena angkutan kota harus mencari penumpang.

\section{3) Jam Operasional}

Tingkat kepuasan masyarakat terkait jam operasional Angkutan Kota dan Angkutan Online dapat dilihat pada Gambar 18 berikut ini

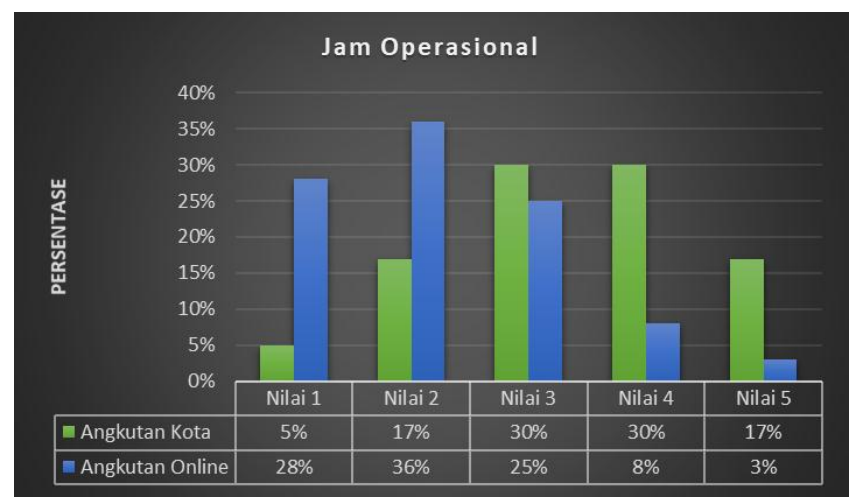

Gambar 18 Penilaian Kinerja Angkutan Umum

Berdasarkan Jam Operasi

Berdasarkan Gambar 18 dapat diketahui bahwa tingkat kepuasan masyarakat terkait jam operasional Angkutan Kota dan Angkutan Online 50\% memberikan nilai diatas nilai rata-rata. Hal ini didukung dengan jam operasional angkutan kota dan angkutan online yang sudah dapat memenuhi kebutuhan perjalanan masyarakat. Untuk angkutan online memiliki jam operasi yaitu 24 jam, dimana masyarakat dapat menggunakan jasanya kapanpun tergantung apakah terdapat driver yang merespon sehingga penilaian masyarakat terkait jam operasi angkuran online
$<50 \%$ diatas nilai rata-rata. Sedangkan angkutan kota beroperasi sejak pukul 06.00 hingga 21.00. Namun terdapat beberapa angkutan kota yang sudah berhenti beroperasi setelah pukul 18.00, sehingga beberapa masyarakat kesulitan mendapatkan angkutan kota ketika malam hari.

4) Kapasitas Kendaraan

Kapasitas kendaraan angkutan kota dan angkutan berbasis online yang dimaksud adalah jumlah penumpang yang terdapat di angkutan umum tersebut ketika responden menggunakannya.

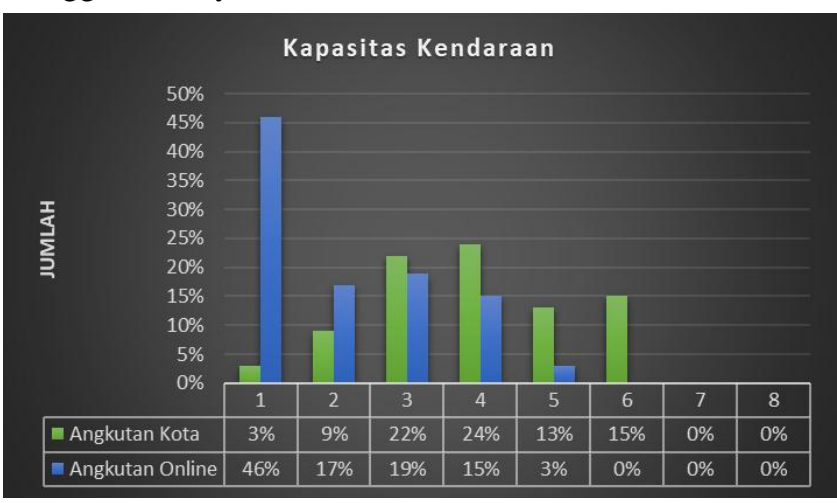

Gambar 19 Kapasitas Kendaraan Angkutan Umum dan Angkutan Berbasis Online

Kapasitas angkutan umum adalah 10 penumpang, sedangkan angkutan berbasis online untuk mobil adalah 4-5 penumpang tergantung mobil yang digunakan dan untuk motor memiliki kapasitas 1 orang. Berdasarkan gambar 19 jumlah penumpang terbanyak untuk angkutan umum adalah ketika sekitar 3-4 penumpang, sedangkan angkutan online jumlah penumpang terbanyak adalah 1 penumpang. Kapasitas kendaraan ini berkaitan dengan tingkat kenyamanan penumpang yaitu berhubungan tentang tidak desak-desakan dan selalu mendapatkan tempat duduk.

\section{Kesimpulan dan Saran}

Berdasarkan hasil pengelompokkan faktor angkutan konvensional, didapatkan 4 faktor yang terbentuk, sedangkan untuk angkutan online, didapatkan 2 faktor yang terbentuk. Berdasarkan hasil analisis regresi linier berganda diketahui kekuatan dari masing-masing indikator yang mempengaruhi dari analisis faktor. Untuk angkutan kota indikator yang memberikan pengaruh signifikan terhadap Y memiliki urutan indikator yang paling besar berpengaruh hingga yang terkecil berdasarkan nilai konstanta adalah sebagai berikut biaya transportasi, waktu terjadinya perjalanan, jarak perjalanan, waktu tunggu, jam operasi, keamanan, kebersihan. Sedangkan untuk angkutan online indikator tersebut dapat diurutkan dari indikator yang memiliki pengaruh paling besar hingga indikator dengan pengaruh paling kecil berdasarkan nilai koefisien indikator tersebut, urutannya yaitu aksesibilitas, waktu perjalanan, jam operasi, kapasitas kendaraan, pengalaman perjalanan, biaya transportasi, keamanan, waktu tunggu, kecepatan kendaraan, dan jarak perjalanan. 


\section{Daftar Pustaka}

Anonymous, 2017, Dinas Perhubungan Kota Makassar. Data - data Trayek dan Rute Angkutan Umum di Kota Makassar.

Badan Pusat Statistik Kota Makassar. 2020. Kota Makassar dalam Angka 2020 : Badan Pusat Statistik Kota Makassar. Makassar.

Borhan, M. N., Syamsunur, D., Akhir, N. M., Yazid, M. R., Ismail, A., \& Rahmat, R. A. (2014). Predicting the Use of Public Transportation: A Case Study from Putrajaya, Malaysia. The Scientific World Journal, 19.

Darmawan, D. (2014). Metode Penelitian Kuantitatif. Bandung: PT Remaja Rosdakarya.

Diab, E., Lierop, D. V., \& Geneidy, A. E. (2017). Recommending Transit Disentangling users' willingness to recommend transit and their intended continued use for publication. Travel Behaviour and Society, 1-27.

Harish, A. G., \& Wardhana, A. 2016. Analisis FaktorFaktor Pembentuk Preferensi Konsumen Go-Jek di Kota Jakarta. e-Proceeding of Management, 2060.

Hardyanti Putri Harsono, N., Syafri, S., \& Jufriadi, J. (2020). Pengaruh Pembangunan Makassar New Port Terhadap Sosial Ekonomi Ditinjau Dari Persepsi Masyarakat. Journal of Urban Planning Studies, 1(1), 042-049.

Ismail, R., Hafezi, M. H., Nor, R. M., \& Ambak, K. (2012). Passengers Preference and Satisfaction of Public Transport in Malaysia. Australian Journal of Basic and Applied Sciences, 410-416.

Narwis, Bachtiar Rezkiawan. 2017. Analisis Permintaan TaksiKonvensional di Tengah Beroperasinya Taksi Online di Kota Makassar. Program Magister Ekonomi Pembangunan dan Perencanaan. Tesis: Universitas Hasanuddin.

RTRW Kota Makassar tahun 2015-2034. Pengarang, : Pemerintah Kota Makassar. Penerbit,: Pemerintah Kota Makassar.

St Maryam H. (2020). Analisis Penyebab Penurunan Minat Pengguna Angkutan Umum Mikrolet Di Kota Makassar. https://doi.org/10.17605/OSF.IO/2CFQM.

Sugiyono, 2009. Metode Penelitian Kuantitatif, Kualitatif dan R\&D, Bandung: Alfabeta.

Sugiyono. 2014. Metode Penelitian Pendidikan Pendekatan Kuantitatif, Kualitatif, dan R\&D. Bandung: Alfabeta.

Susilowati, Wicaksono, A., \& Suharso, T. W. (2011). Kajian Kinerja Angkutan Umum Dengan Metode Quality Function Deployemnt (QFD) pada Kawasan Industri Marmer di Kabupaten Tulungagung. Jurnal Rekayasa Sipil.

Tamin, O.Z. 2000. Perencanaan dan Pemodelan Transportasi. Edisi Kedua. Penerbit Institut Teknologi Bandung, Bandung.

Trynopoulos, Y., \& Antoniou, C. (2008). Public transit user satisfaction: Variability and policy implications. Transport Policy, 260-272. 